ARTYKUŁY

Studenckie Zeszyty Naukowe 2019, Vol. XXII, nr 40

DOI: 10.17951/szn.2019.22.40.127-135

Ilona Radziwon-Kamińska

Uniwersytet w Białymstoku

radziwonilona@o2.pl

\title{
Organizacja ekologiczna jako podmiot w postępowaniu administracyjnym. Wybrane zagadnienia
}

\author{
The ecological organization as a party to administrative \\ proceedings. Selected issues
}

\section{STRESZCZENIE}

W artykule podjęto problematykę udziału organizacji ekologicznej w postępowaniu administracyjnym. Wskazano na status prawny organizacji ekologicznej. Omówiono także uprawnienia organizacji ekologicznej w toku postępowania administracyjnego. Ponadto Autorka wyodrębniła przypadki, w których organizacja ekologiczna może brać udział w postępowaniu administracyjnym na prawach strony. Przyjęto metodologię dogmatycznoprawną. Artykuł został wzbogacony o aktualne stanowisko doktryny i orzecznictwa.

Słowa kluczowe: organizacja ekologiczna, cechy oraz uprawnienia organizacji ekologicznej, postępowanie administracyjne $\mathrm{z}$ udziałem organizacji ekologicznej

\section{WPROWADZENIE}

Organizacja ekologiczna jest organizacją społeczną, która stanowi podmiot postępowania administracyjnego, a tym samym wpisuje się w zakres szeroko rozumianego prawa administracyjnego, a w zasadzie prawa administracyjnego procesowego.

Celem artykułu jest omówienie uprawnień jakie posiada organizacja ekologiczna w postępowaniu administracyjnym oraz wskazanie przypadków, w których będzie mogła ona brać udział jako strona postępowania administracyjnego. Istotne wydaje się również określenie zakresu działań jakie mogą podjąć organizacje ekologiczne w obrębie ich działalności. Rozważania prowadzą również do wskazania roli, jaką pełnią organizacje ekologiczne w postępowaniu administracyjnym oraz dokonania oceny ich funkcjonowania. 


\section{POJECIE ORGANIZACJI EKOLOGICZNEJ}

Definicja legalna pojęcia „organizacja ekologiczna” zawarta jest w ustawie z dnia 3 października 2008 r. o udostępnianiu informacji o środowisku i jego ochronie, udziale społeczeństwa w ochronie środowiska oraz o ocenach oddziaływania na środowisko ${ }^{1}$. Organizacją ekologiczną jest taka organizacja społeczna, której statutowym celem jest ochrona środowiska (art. 3 ust. 1 pkt 10 u.o.o.ś.).

Niezbędnym elementem postępowania przed organem administracji publicznej kwalifikującego daną organizację społeczną jako ekologiczną jest ustalenie czy jej statutowe cele odnoszą się do szeroko rozumianej ochrony środowiska. Analizując dalej można stwierdzić, iż w pojęciu ochrony środowiska mieści się podjęcie lub zaniechanie działań, umożliwiające zachowanie lub przywracanie równowagi przyrodniczej. Ochrona ta polega w szczególności na:

a) racjonalnym kształtowaniu środowiska i gospodarowaniu zasobami środowiska zgodnie z zasadą zrównoważonego rozwoju,

b) przeciwdziałaniu zanieczyszczeniom,

c) przywracaniu elementów przyrodniczych do stanu właściwego (art. 3 pkt 13 p.o.ś. $)^{2}$.

W związku z powyższym w literaturze przedmiotu podkreśla się, iż pojęcie ochrony środowiska ma szeroki zakres przedmiotowy. W konsekwencji większość spraw mieszczących się w kategorii ochrony środowiska sprawia, że ewentualne uczestnictwo organizacji ekologicznych w poszczególnych postępowaniach administracyjnych również może mieć szeroki zakres przedmiotowy ${ }^{3}$.

Ciekawe stanowisko zaprezentowała J. Ciechanowicz-McLean twierdząc, iż pozycję prawną organizacji ekologicznej wyznacza status obywateli lub grup oraz innych podmiotów niezależnych od władzy publicznej. Pozycja ta jest o tyle silna, o ile organizacja ekologiczna ma zapewnioną możliwość udziału w postępowaniu sądowym ${ }^{4}$. Jeśli chodzi o przedmiot działalności organizacji ekologicznej to zaliczyć należy tu wszystko, co mieści się w pojęciu środowiska oraz jego ochrony począwszy od zanieczyszczeń środowiska, po edukację ekologiczną 5 .

Co więcej, Wojewódzki Sąd Administracyjny w Szczecinie stwierdził, iż przy kwalifikacji organizacji społecznej jako organizacji ekologicznej wystarczy, że jej działalność nawet w minimalnym stopniu jest związana z ekologią ${ }^{6}$.

1 Dz. U. z 2017 r. poz. 1999, dalej jako: "u.o.o.ś.".

2 Ustawa z dnia 27 kwietnia 2001 r. Prawo ochrony środowiska, Dz. U. z 2018 r. poz. 650, dalej jako: "p.o.ś.".

3 K. Gruszecki, Udziat organizacji ekologicznych w postepowaniu administracyjnym w sprawach ochrony środowiska, "Państwo i Prawo", 2002 r., nr 2, str. 88-90.

4 J. Ciechanowicz- McLean, Leksykon ochrony środowiska, s. 220.

5 Ibidem.

6 Wyrok WSA w Szczecinie z dnia 20 lipca 2011 r. II SA/Sz 980/10, Legalis nr 385115. 
Uzasadnienie udziału konkretnej organizacji ekologicznej działającej w zakresie ochrony środowiska $\mathrm{w}$ danym postępowaniu administracyjnym (stosownie do treści art. 3 ust. 1 pkt 10 - pojęcie organizacji ekologicznej i 44 ust. 2 u.o.o.ś.wniesienie odwołania od decyzji) musi wynikać bezpośrednio z jej statutu? W doktrynie podnosi się jednak, że postanowienia tego aktu ustrojowego nie muszą być precyzyjne. Czasami może wystarczyć przepis nakładający obowiązek dbałości o jakiś element środowiska. Cel ten musi jednak pozostawiać w związku z przedmiotem konkretnego postępowania administracyjnego ${ }^{8}$.

W orzecznictwie pojawia się także pogląd, w myśl którego musi istnieć merytoryczne w sensie prawnym powiązanie przedmiotu postępowania administracyjnego z celami statutowymi i zakresem działania tej organizacji społecznej, a nie tylko powiązania faktyczne ${ }^{9}$. Organ administracji publicznej (wojewoda) na podstawie cytowanego z orzecznictwa NSA poglądu stwierdził, iż statut stowarzyszeń ekologicznych powinien wprost określać możliwość udziału tego typu stowarzyszenia w postępowaniach administracyjnych związanych z wydawaniem decyzji rozstrzygających kwestie z zakresu ochrony środowiska ${ }^{10} . \mathrm{Z}$ analizy orzecznictwa wynika, iż wiele organów badając zasadność dopuszczenia organizacji ekologicznej jako strony w postępowaniu administracyjnym twierdzi, że cel statutowy musi pozostawać w związku z przedmiotem konkretnego postępowania administracyjnego ${ }^{11}$.

Kodeks postępowania administracyjnego ${ }^{12}$ dopuszcza do udziału w postępowaniu administracyjnym organizację społeczną na prawach strony. W myśl definicji legalnej zawartej w art. $5 \S 2$ pkt 5 k.p.a., organizacje społeczne to organizacje zawodowe, samorządowe, spółdzielcze i inne organizacje społeczne. Określona w statucie organizacji społecznej jej działalność, a więc w istocie cele organizacji społecznej, muszą być w stopniu możliwie ścisłym określone, tak aby dawały możliwość ustalenia, że wiążą się ściśle z przedmiotem sprawy, do udziału w której organizacja zamierza przystąpić na prawach strony. Bezzasadne jest stanowisko, iż w sytuacji, w której organizacja społeczna za pomocą ogólnikowych stwierdzeń stara się wykazać istnienie interesu społecznego, to wówczas niejako na organ administracji publicznej przechodzi ciężar ustalenia istnienia tego interesu. Za udziałem organizacji społecznej w postępowaniu ad-

${ }^{7}$ Ibidem.

${ }^{8} \mathrm{~K}$. Gruszecki, Udział organizacji ekologicznych w postępowaniu administracyjnym w sprawach ochrony środowiska, Państwo i Prawo 2002, nr 2, s. 93.

${ }^{9}$ Wyrok NSA z dnia 20 listopada 2012 r., II OSK 1308/11.

10 Zob. Wyrok NSA z dnia 3 marca 2016 r., II OSK 1674/14, Legalis nr 1469919.

${ }_{11}$ Zob. Wyrok WSA w Szczecinie z dnia 20 lipca 2011 r., II SA/SZ 980/10, Legalis nr 816956.

12 Ustawa z dnia 14 czerwca 1960 r. Kodeks postępowania administracyjnego, Dz. U. z 2018 r., poz. 650 , dalej jako: "k.p.a.". 
ministracyjnym interes społeczny przemawiał będzie tylko wtedy, gdy będzie ona dysponowała wiedzą merytoryczną w kwestiach objętych swoimi celami statutowymi, ale i rozeznaniem w sprawie, w której ma uczestniczyć1 ${ }^{13}$.

\section{ORGANIZACJA EKOLOGICZNA JAKO STRONA POSTĘPOWANIA ADMINISTRACYJNEGO}

Kluczowymi aktami w kwestii uprawnień organizacji ekologicznej w postępowaniu administracyjnym jest Kodeks postępowania administracyjnego oraz ustawa o udostępnianiu informacji o środowisku i jego ochronie, udziale społeczeństwa W ochronie środowiska oraz o ocenach oddziaływania na środowisko. W pierwszym akcie prawnym wskazane zostały przez ustawodawcę uprawnienia ogólne organizacji społecznej (w tym ekologicznej), natomiast w drugim - uprawnienia szczegółowe organizacji ekologicznej w postępowaniu wymagającym udziału społeczeństwa.

Zgodnie z art. 31 § 1 i 3 k.p.a., organizacja społeczna, jaką jest organizacja ekologiczna, może zostać dopuszczona do udziału w postępowaniu administracyjnym na prawach strony, o ile zostaną jednocześnie spełnione trzy przesłanki. Po pierwsze, dotyczy to osoby trzeciej. Po drugie, uzasadnione jest to celami statutowymi. Po trzecie, gdy przemawia za tym interes społeczny. Wówczas organizacja taka może żądać m.in. wszczęcia postępowania, jak również dopuszczenia jej do udziału w postępowaniu.

Właściwy organ administracji publicznej, uznając żądanie organizacji społecznej za uzasadnione, postanawia o wszczęciu postępowania z urzędu lub o dopuszczeniu organizacji do udziału w postępowaniu. Na postanowienie o odmowie wszczęcia postępowania lub dopuszczenia do udziału w postępowaniu organizacji społecznej służy zażalenie (art. $31 \S 2$ k.p.a.).

$\mathrm{Z}$ art. 44 ust. 1 ustawy o udostępnianiu informacji o środowisku (...) wynika, że do organizacji ekologicznych nie ma zastosowania art. $31 \S 4$ k.p.a. Oznacza to, że organ administracji publicznej, wszczynając postępowanie w sprawie dotyczącej innej osoby, nie zawiadamia o tym organizacji ekologicznej, nawet jeśli uzna, że może ona być zainteresowana udziałem w tym postępowaniu ze względu na swoje cele statutowe, i gdy przemawia za tym interes społeczny. Przepisy te mają szczególne znaczenie z uwagi na to, że wskazują różnicę między organizacją społeczną a organizacją ekologiczną.

W przypadku, gdy organizacja ekologiczna, powołując się na swoje cele statutowe i art. 44 ustawy o udostępnianiu informacji o środowisku (...) zgłasza

\footnotetext{
${ }^{13}$ Wyrok WSA w Krakowie z dnia 1 lipca 2016 r., II SA/Kr 449/16, Legalis nr 1538858.
} 
chęć uczestniczenia w postępowaniu, obowiązkiem organów administracji jest ustalenie, czy jest to postępowanie wymagające udziału społeczeństwa ${ }^{14}$.

Odnośnie wykazania interesu społecznego organizacji społecznej, co również bezpośrednio dotyczy organizacji ekologicznej, Naczelny Sąd Administracyjny stwierdził, iż nie wystarczy ogólnikowe sformułowanie przez organizację społeczną, że działa w interesie społecznym, powoływanie się na ochronę środowiska, ochronę zdrowia czy życia ludzi, bo są to cele wskazane bardzo ogólnie i na tej zasadzie każda organizacja musiałaby być dopuszczona do udziału w każdym postępowaniu. Chodzi o to, aby powołując się na interes społeczny, który jest interesem ogólnym, organizacja nie używała ogólnikowych stwierdzeń, lecz wskazywała konkretne okoliczności faktyczne, prawne, które mogą świadczyć o tym, że powinna w tym postępowaniu uczestniczyć ${ }^{15}$.

Do podstawowych uprawnień organizacji ekologicznej w postępowaniu administracyjnym z zakresu ochrony środowiska należą:

1) uczestniczenie na prawach strony w postępowaniu administracyjnym dopuszczającym udział społeczeństwa, o ile prowadzą działalność statutową w zakresie ochrony środowiska lub ochrony przyrody, przez minimum 12 miesięcy przed dniem wszczęcia tego postępowania (art. 44 ust. 1 u.o.o.ś.);

2) prawo wniesienia odwołania od decyzji wydanej w postępowaniu wymagającym udziału społeczeństwa, jeżeli jest to uzasadnione celami statutowymi tej organizacji, także w przypadku, gdy nie brała ona udziału w określonym postępowaniu wymagającym udziału społeczeństwa prowadzonym przez organ pierwszej instancji. Wniesienie odwołania jest równoznaczne ze zgłoszeniem chęci uczestniczenia w takim postępowaniu. W postępowaniu odwoławczym organizacja uczestniczy na prawach strony (art. 44 ust. 2 u.o.o.ś.);

3) możliwość wniesienia skargi do sądu administracyjnego od decyzji wydanej w postępowaniu wymagającym udziału społeczeństwa, jeżeli jest to uzasadnione celami statutowymi tej organizacji, także w przypadku, gdy nie brała ona udziału w określonym postępowaniu wymagającym udziału społeczeństwa (art. 44 ust. 3 u.o.o.ś.);

4) składanie wniosków dowodowych (np. powołanie biegłego).

Uprawnienia szczególne organizacji ekologicznej wynikające z art. 44 u.o.o.ś. dotyczą tych postępowań administracyjnych, w których wymagany jest udział społeczeństwa. Podkreślić należy, iż nie ma jednego aktu prawnego zawierającego katalog postępowań administracyjnych z zakresu ochrony środowiska, w których wymagany jest udział społeczeństwa, w tym organizacji ekologicznej. Jak podkreślają przedstawiciele doktryny katalog postępowań jest rozproszony w wielu

${ }^{14}$ B. Adamiak (red.), Komentarz do artykutu 31 Kodeksu postępowania administracyjnego [w:] B. Adamiak, J. Borkowski, Kodeks postępowania administracyjnego: komentarz, dostęp: Legalis nr 1009098.

15 Wyrok NSA z dnia 5 listopada 2014 r., II OSK 985/13, Legalis nr 1329050. 
aktach prawnych. Jak twierdzi T. Filipowicz "nie można się zgodzić z wyrażanymi wcześniej przez przedstawicieli doktryny poglądami, iż katalog postępowań wymagających udziału społeczeństwa nie jest określony i trudno ustalić, o jakie postępowania chodzi (B. Rakoczy, Ustawa o udostępnianiu informacji, komentarz do art. 44 ustawy, pkt 3) lub że należy go ustalać w oparciu o pojęcie ochrony środowiska (K. Gruszecki, Ustawa o udostępnianiu informacji, komentarz do art. 44 ustawy, pkt II). Należy przy tym wskazać, że przepisy prawa określające katalog postępowań wymagających udziału społeczeństwa są rozproszone po różnych ustawach, dlatego też precyzyjne wskazanie wszystkich elementów tego katalogu może sprawiać pewne problemy"16.

$\mathrm{Z}$ analizy orzecznictwa wynika również, iż to czy w postępowaniu administracyjnym może brać udział społeczeństwo musi wynikać wyłącznie z konkretnego przepisu prawnego ${ }^{17}$.

Do postępowań administracyjnych wymagających udziału społeczeństwa, w których może wziąć udział organizacja ekologiczna nalezą postępowania prowadzące do wydania:

1) decyzji o środowiskowych uwarunkowaniach dotyczącej zgody na realizację przedsięwzięcia, w ramach którego przeprowadza się ocenę oddziaływania przedsięwzięcia na środowisko (art. 79 ust. 1 u.o.o.ś);

2) decyzji o pozwoleniu na budowę, o zatwierdzeniu projektu budowlanego, o pozwoleniu na wznowienie robót, o zezwoleniu na realizację inwestycji drogowej, o zezwoleniu na realizację inwestycji w zakresie lotniska użytku publicznego oraz o pozwoleniu na realizację inwestycji (w zakresie budowli przeciwpowodziowych), w ramach którego przeprowadza się ponowną ocenę oddziaływania na środowisko (art. 90 ust. 2 pkt 1 u.o.o.ś.);

3) decyzji wymaganej przed rozpoczęciem realizacji przedsięwzięcia, innego niż przedsięwzięcie mogące znacząco oddziaływać na środowisko, które nie jest bezpośrednio związane z ochroną obszaru Natura 2000 lub nie wynika z tej ochrony, jeśli regionalny dyrektor ochrony środowiska stwierdził potrzebę oceny oddziaływania przedsięwzięcia na obszar Natura 2000 (art. 98 ust. 4 u.o.o.ś.);

4) decyzji o udzieleniu pozwolenia zintegrowanego dla nowo zbudowanej instalacji, o wydaniu pozwolenia zintegrowanego z odstępstwem, o którym mowa w art. 204 ust. 2 p.o.ś., o zmianie pozwolenia zintegrowanego

${ }_{16}$ T. Filipowicz, Komentarz do art. 44 [w:] red. T. Filipowicz, A. Plucińska-Filipowicz, M. Wierzbowski, Ustawa o udostępnianiu informacji o środowisku i jego ochronie, udziale społeczeństwa w ochronie środowiska oraz o ocenach oddziaływania na środowisko. Komentarz, Warszawa 2017, dostęp: Legalis.

17 Zob. Wyrok WSA w Bydgoszczy z dnia 1 marca 2016 r., II SA/Bd 1353/15, Legalis nr 1474054; Wyrok WSA w Szczecinie z dnia 14 stycznia 2016 r., II SA/Sz 1097/15, Legalis nr 1447108. 
polegającej na udzieleniu takiego odstępstwa oraz o wydaniu lub zmianie pozwolenia zintegrowanego dotyczącej istotnej zmiany instalacji (art. 185 ust. 2a oraz art. 218 p.o.ś.);

5) decyzji o wydanie zgody na zamknięte użycie GMM, zamknięte użycie GMO lub zamierzone uwolnienie GMO do środowiska oraz zezwolenia na prowadzenie zakładu inżynierii genetycznej lub wprowadzenie do obrotu produktu GMO (art. 14 u.g.z. ${ }^{18}$ );

6) decyzji o wydaniu zezwolenia dotyczącego instalacji do termicznego przekształcania odpadów lub decyzji o zmianie tego zezwolenia (art. 42 ust. 7 u.o. $\left.{ }^{19}\right)$.

Współcześnie wiele organizacji ekologicznych dąży do dopuszczenia ich do udziału w postępowaniu administracyjnym bądź skorzystania z prawa do złożenia odwołania od decyzji. Często celem tych działań procesowych jest wydłużenie postępowania administracyjnego prowadzącego do uzyskania przez przedsiębiorcę (inwestora) stosownych zezwoleń. Sąd Najwyższy stwierdził, iż niedopuszczalne jest określenie przez organizację ekologiczną celu na który mają być przeznaczone świadczenia majątkowe przekazane przez przedsiębiorcę (inwestora) w celu uniknięcia przedłużenia postępowania administracyjnego prowadzącego do uzyskania stosownych zezwoleń. Wówczas umowa zawarta między organizacją ekologiczną a przedsiębiorcą (inwestorem) skutkuje nieważnością zawartej w tym przedmiocie umowy, jako sprzecznej z zasadami współżycia społecznego (art. 58 § 2 k.c. $\left.^{20}\right)^{21}$.

\section{WNIOSKI}

Organizacja ekologiczna jest organizacją społeczną, która może wziąć udział w postępowaniu administracyjnym z zakresu ochrony środowiska na prawach strony pod warunkiem, iż jej statutowym celem jest szeroko rozumiana ochrona środowiska. Oprócz tego organizacja ekologiczna musi wykazać, iż jej udział w postępowaniu administracyjnym jest istotny z uwagi na interes publiczny.

Najczęściej pojawiającym się problemem w toku postępowania administracyjnego po stronie organów administracji publicznej jest błędna kwalifikacja organizacji ekologicznej jako podmiotu na prawach strony, a tym samym niedopuszczenie jej do udziału w postępowaniu. Niekiedy organy administracji publicznej zbyt

${ }^{18}$ Ustawa z dnia 22 czerwca 2001 r. o mikroorganizmach i organizmach genetycznie zmodyfikowanych, Dz. U. z 2018 r., poz. 810, dalej jako: "u.g.z.".

${ }^{19}$ Ustawa z dnia 14 grudnia 2012 o odpadach, tj. Dz. U. 2018 poz. 992, dalej jako:" u.o.".

${ }^{20}$ Ustawa z dnia 23 kwietnia 1964 r. Kodeks cywilny, Dz. U. z 2017 r. poz. 650, dalej jako: "k.c.".

${ }^{21}$ Wyrok SN z dnia 10 listopada 2004 r., II CK 202/04, Legalis nr 67723. 
wąsko oceniają zasadność udziału organizacji w postępowaniu w związku z jej statutowymi celami, mimo iż w doktrynie i orzecznictwie funkcjonuje szeroka interpretacja ochrony środowiska i celów statutowych organizacji ekologicznej.

Współcześnie organizacje ekologiczne odgrywają dużą rolę w postępowaniu administracyjnym. Z jednej strony mogą wpłynąć na wydłużenie postępowania administracyjnego, a tym samych wydłużyć czas dokonania rozstrzygnięcia przez właściwy organ administracji publicznej, a w konsekwencji opóźnić realizację jakiejś inwestycji/inicjatywy/działania. $Z$ drugiej zaś, mogą bronić słuszności interesów obywateli czy też danej społeczności lokalnej w sprawach z zakresu prawa ochrony środowiska. Co więcej spełniają także funkcję ochronną w stosunku do środowiska, co może skutkować wstrzymaniem lub zablokowaniem danej inwestycji/inicjatywy/przedsięwzięcia do czasu znalezienia przez inwestora wariantu najkorzystniejszego z perspektywy środowiska, wpisującego się w zasadę zrównoważonego rozwoju.

\section{BIBLIOGRAFIA}

Adamiak B., Komentarz do artykułu 31 Kodeksu postepowania administracyjnego [w:] red. B. Adamiak, J. Borkowski, Kodeks postępowania administracyjnego. Komentarz., Legalis

Ciechanowicz-McLean J. (red.), Leksykon ochrony środowiska, Warszawa 2009

Filipowicz T., Komentarz do art. 44 [w:] red. T. Filipowicz, A. Plucińska-Filipowicz, M. Wierzbowski, Ustawa o udostępnianiu informacji o środowisku i jego ochronie, udziale społeczeństwa w ochronie środowiska oraz o ocenach oddziaływania na środowisko. Komentarz, Warszawa 2017, Legalis.

Gruszecki K., Udziat organizacji ekologicznych $w$ postępowaniu administracyjnym $w$ sprawach ochrony środowiska, „Państwo i Prawo” 2002 r., nr 2

Ustawa z dnia 14 czerwca 1960 r. Kodeks postępowania administracyjnego, Dz. U. z 2018 r., poz. 650 Ustawa z dnia 14 grudnia 2012 o odpadach, tj. Dz. U. 2018 poz. 992

Ustawa z dnia 22 czerwca 2001 r. o mikroorganizmach i organizmach genetycznie zmodyfikowanych, Dz. U. z 2018 r., poz. 810

Ustawa z dnia 23 kwietnia 1964 r. Kodeks cywilny, Dz. U. z 2017 r. poz. 650.

Ustawa z dnia 27 kwietnia 2001 r. Prawo ochrony środowiska, Dz. U. z 2018 r. poz. 650.

Wyrok NSA z dnia 20 listopada 2012 r., II OSK 1308/11, Legalis nr 816956.

Wyrok NSA z dnia 3 marca 2016 r., II OSK 1674/14, Legalis nr 1469919.

Wyrok NSA z dnia 5 listopada 2014 r., II OSK 985/13, Legalis nr 1329050.

Wyrok SN z dnia 10 listopada 2004 r., II CK 202/04, Legalis nr 67723

Wyrok WSA w Bydgoszczy z dnia 1 marca 2016 r., II SA/Bd 1353/15, Legalis nr 1474054;

Wyrok WSA w Szczecinie z dnia 14 stycznia 2016 r., II SA/Sz 1097/15, Legalis nr 1447108.

Wyrok WSA w Krakowie z dnia 1 lipca 2016 r., II SA/Kr 449/16, Legalis nr 1538858.

Wyrok WSA w Szczecinie z dnia 20 lipca 2011 r. II SA/Sz 980/10, Legalis nr 385115.

Wyrok WSA w Szczecinie z dnia 20 lipca 2011 r., II SA/SZ 980/10, Legalis nr 385115. 
Pobrane z czasopisma Studenckie Zeszyty Naukowe http://szn.umcs.pl

Data: 26/04/2023 13:02:44

Organizacja ekologiczna jako podmiot w postępowaniu administracyjnym...

\section{SUMMARY}

The article presents the problems of participation of an environmental organization in administrative proceedings. The legal status of an ecological organization was indicated. The rights of the ecological organization during the administrative proceedings were also discussed. In addition, the author has identified cases in which an environmental organization may take part in administrative proceedings on the parties' rights. The dogmatic methodology was adopted. The article has been enriched with the current position of doctrine and jurisprudence.

Key words: ecological organization, features and powers of the ecological organization, administrative proceedings with the participation of an environmental organization 